\title{
The universal imperial power of the Christian Text and yet the vulnerability of its message
}

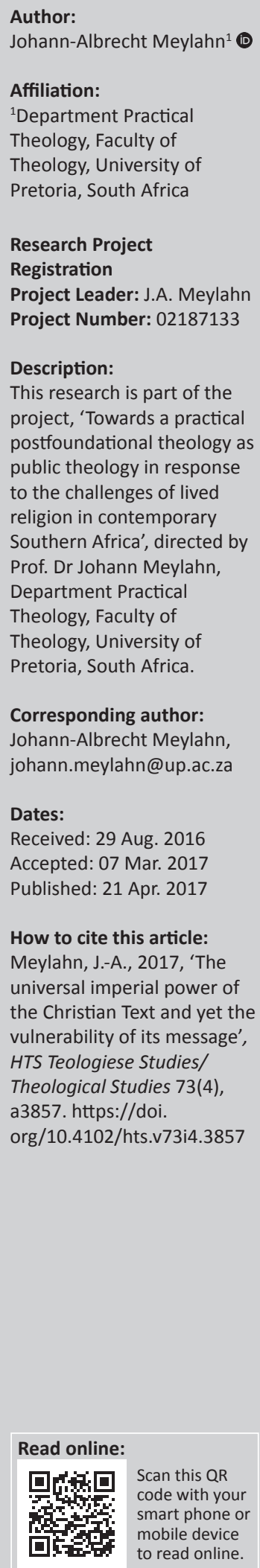

Is there anything outside the Christian Text or is the Christian Text all there is? The article will argue that the Christian Text has formed and shaped Western thinking to such an extent that it is impossible to think in the global world, co-created by various Western texts, without Christianity. The fact that the West colonised the world, and that today the Western media dominates the language of the global village, makes it nearly impossible to think outside the Christian Text and thus the universal domination by the Text. This article will first argue that for the Western-influenced world, there is nothing beyond the Christian Texts, and then it will argue that although this Text has universal (global) dominance, there is an interpretation of its central message as a message of weakness and vulnerability, which challenges (deconstructs) its imperialism. This leads towards the question: what is a possible praxis of such a universal and 'imperial' Text with its message of vulnerable weakness, specifically from a post-colonial context like South Africa?

\section{Introduction}

Is there anything outside the Christian Text or is the Christian Text all there is? ${ }^{1}$ This is a strange question to ask and maybe even a dangerous thought, in a time when the media portrays the recent attacks in Paris as a battle between religious fundamentalism and so-called freedom of speech (the attack on Charlie Hebdo magazine on 07 January 2015 and the various other attacks in France, Belgium and Germany since then). Is one not, by making such claims, fanning the flames of religious fundamentalism or religious exclusivism? The fact that there was such an attack in the name of ... and the numerous counter protests in the name of ... clearly defies any universalist and exclusive claims, because there clearly are other texts beside the Christian Text. These incidents bring at least two other texts into play, or rather, this is how it is portrayed in some media: in the name of the prophet of God and in the name of the Western value of 'secular' free speech:

- Therefore, there are other texts than the Christian Text.

- There are always other texts!

- How can one in one paragraph say two seemingly opposing things? There is only the Christian Text and there are always other texts!

When I refer to the Christian Text, I am not only referring to the Bible but also referring to the socialcultural-political fabric from which the Western world is woven. I am referring to the Christian sign system that is, according to Deleuze and Guattari, made up of the two sign systems, namely the signifying sign regime (or Greek sign system of the Logos and the concentric circles circuling around the logos that gives meaning to all) and the prophetic sign system (or the postsignifying sign regime) (Deleuze \& Guattari 2011:111-148). This idea that the Christian sign systems include these opposites or that these opposites together form the Christian sign regime and therefore the Christian grammar is echoed in Jean-Luc Nancy's argument, when he argues that both the enclosure as well as the disenclosure would be Christian (Nancy 2008:9-11). Or to translate this into the thought of Enrique Dussel (1985:48), both the Western Ontology as well as his Metaphysics of liberation could be interpreted as Christian. In other words, any attempt at escaping the ontology or enclosure or Greek sign system via a prophetic sign system or to try and break open the enclosure via a disenclosure, or via Dussel's metaphysics of liberation, remains within the Christian sign system, which comprises these two sign systems. It is in this sense that I argue there is nothing outside the Christian Text, it is in this sense that Deleuze and Guattari argue that the face of Christ is the abstract machine of the West.

1.This is a play on the famous text by Derrida, 'There is nothing outside of the text [there is no outside-text; il n'y a pas de horstexte]' (Derrida 1997:158).

Note: This paper was made possible through the Alexander von Humboldt Fellowship for experienced researchers, 2014-2016. 


\section{And what has this got to do with power?}

It has everything to do with power. In a certain sense, it has to do with absolute power. Who has the power to create the world? Whose language creates the world we are living in, or whose language allows the dominant world to appear? Who has the power to interpret the world? Who has the power to say what happened in Paris on 07 January 2015 and why is that happening more newsworthy than what happened in Baga (03-07 January 2015) in Nigeria? Why is Baga not a world-historical event, where world leaders gather in protest?

It has to do with the kind of world that appears and in which one lives. Things happen, yet what happened depends on who is interpreting, and by interpreting or giving meaning transforming what happened into events, and even worldhistorical events.

In this sense, it has to do with public practical theology and how one engages with the powers that firstly allow to appear, then interpret and then act (respond) on the basis of these interpretations of events in particular worlds. Or maybe it has to do with how one, as practical theologian, responds to the victims of these powers that allow to appear, interpret and then act on the basis of their interpretations.

What do I mean when I say there is nothing outside the Christian Text? Thereby I am certainly not stating that everybody is Christian or that everything is Christian, as there are numerous examples to the contrary. What I am arguing is that the appearance of the West, what is happening in the West and the interpretations thereof, appear, are events and are interpreted within the Christian Text among other texts. Or as Mark Taylor argues, 'You cannot understand the world today if you do not understand religion' (Taylor 2007:54 of 6286). He argues that secularism and religion are not opposites, but that secularity is a religious phenomenon (Taylor 2007:pos 59 of 6286). He can say this because he argues that religion is not a 'separate domain but pervades all culture and has an important impact on every aspect of society' (Taylor 2007:59 of 6286).

Capitalism and materialism cannot be seen as outside the Christian Text, thanks to Max Weber's famous argument in The Protestant Ethic and the Spirit of Capitalism, and the role Calvin's theology played in the rise of capitalism (Weber 1930). Mark Taylor agrees with Weber to a point, but argues, by adding the role that Luther played, not only in the Spirit of Capitalism but also in the Spirit of Globalisation (Taylor 2007).

One can argue that secularism, pluralism and relativity, all of which characterise the West, are inspired (inspirited) by the Christian Text (see Taylor 2007). Taylor even argues that the death of God or secularism is already inherent in the early Christology (Taylor 2007:106 of 6286).

On the contrary, there are those who argue that communism is inspirited by the Christian Text and that fundamentalism is a product of monotheism and therefore a direct consequence of the three great monotheisms. All the different products and by-products of modernity and postmodernity can be argued (Taylor 2007:65 of 6286) to be decisively shaped by Christianity and more specifically Protestantism and therefore inside the Christian Text.

How can it be that the same text inspires pluralism, relativism, capitalism, communism as well as fundamentalism, together with free speech and 'freedom'?

\section{There is nothing outside the Christian Text ${ }^{2}$}

There are different approaches to responding to this statement that there is nothing outside the Christian Text. One response is to argue that it is a historical-cultural phenomenon. In other words that Christianity has played such an important role in the cultural development of the West that together with ancient Greek texts and some Arabic texts, they all form the cannon of Western culture and, therefore, will inevitably influence anything that emerges out of these cultural context(s). One could say that Christian Text is part of the grammar of the West, and therefore, it influences and determines anything that is created through the use of that grammar. The Christian Text partly determines the language of this culture, and therefore, anything that emerges from this culture within its language can be traced back to Christian language (Text).

Another possibility is to argue that it is in the nature of these texts to be open to interpretation. The Christian Text as well as texts on communism and capitalism, relativism and pluralism are all open to interpretation, and as such they are open to be inter-interpreted. Yet, such inter-interpretations are only possible because of their common linguistic roots in the Christian Text among other texts.

The language of the West is thus partly determined, and one might even argue dominantly determined, by the Christian Text, although not exclusively. Whatever is translated into the Western idiom will in its translation have Christian elements or elements of Christian grammar. This becomes clear when Westerners try to understand something of Ubuntu. It is amazing how soon theories concerning Ubuntu sound similar to Christianity, but this is because it is translated into Western language (grammar) and Western language is strongly determined by the Christian Text. One finds similar situations when the West meets the East and various Eastern philosophies or religions. Once they are translated into Western language, they sound similar to certain Christian texts. This of course depends on the person translating and the person interpreting, as for some there will be no similarity whatsoever.

2.1 am using the singular and capitalisation for Christian Text, thereby 1 am not denying that there are numerous interpretations of these Texts and that there is no denying that there are numerous interpretations of these Texts and that there is no
singular Text. Therefore, the dual statements: There is nothing outside the Christian singular Text. Therefore, the dual stateme
Text ..., ... there are always other texts. 


\section{The power of the Christian Text}

The impossibility for a Westerner to encounter the other without inscribing the other into the grammar of the Western or Christian Text is illustrated by Deleuze and Guattari, when they speak of the faceless primitive. "Primitives" may have the most human of heads, the most beautiful and most spiritual, but they have no face and need none' (Deleuze \& Guattari 2011:176). The other (primitive) only has a head in relation to the face of the West, the face of Christ:

The reason is simple. The face is not a universal. It is not even that of the white man; it is White Man himself, with his broad white cheeks and the black holes of his eyes. The face is Christ. (Deleuze \& Gauttari 2011:176)

It is the face of Christ that allows one to make that distinction of a faceless primitive:

If the face is in fact Christ, in other words, your average ordinary White Man, then the first deviances, the first divergence-types, are racial: yellow man, black man, men in the second or third category. They are also inscribed on the wall, distributed by the hole. They must be Christianized, in other words, facialized. European racism as the white man's claim has never operated by exclusion, or by the designation of someone as Other: it is instead in primitive societies that the stranger is grasped as an 'other'. Racism operates by the determination of degrees of deviance in relation to the White-Man face, which endeavors to integrate nonconforming traits into increasingly eccentric and backward waves, sometimes tolerating them at given place under given conditions, in a given ghetto, sometimes erasing them from the wall, which never abides alterity (it's a Jew, it's an Arab, it's a Negro, it's a lunatic ...). From the viewpoint of racism, there is no exterior, there are no people on the outside. There are only people who should be like us and whose crime it is not to be. (Deleuze \& Gauttari 2011:178)

Deleuze and Guattari continue and argue that 'It was under the sign of the cross that people learned to steer the face and processes of facialisation in all directions' (Deleuze \& Guattari 2011:179).

\section{Globalisation and the Christian Text}

There is a certain monolingualism at play with the dominance of English or Western language with regard to the global village, thanks to the media and information industry. Everything is translated into this 'language', this Text, and thus, this Text attains a certain imperial universalism. Of course, there are other societies and cultures, who have followed a different path and were influenced (inspired) by different texts, but as Taylor argues, 'with the rise of globalization, it is not exaggeration to say that no society or culture has been untouched by this originally Western movement' (Taylor 2007:65 of 6286).

He continues and argues that 'It is undeniable that, for better and for worse, the world as we know it would not have come about without Protestantism' (Taylor 2007:71 of 6286).

Mark Taylor follows a religious path to unpack the dominance of the Christian Text, specifically for him, the protestant Text.
Jean-Luc Nancy argues in a similar fashion for the universalisation of the Christian Text, but not from a religious point of view, but rather from a philosophical point of view. Nancy follows the linguistic path or philosophy of language in the linguistic turn, a turn that forces us to rethink humanity as such, as well as humanity's relation to the Other and other (2013:4-6).

If one understands the human within the context of language, then the world, as well as the existence of the world, appears through language. Humanity is then that which addresses, and in addressing creates, yet it is also that which is addressed by its own creation. In this address, there is no final response (Nancy 2013:6). It is here in this address or adoration that Nancy places God, specifically the gods of monotheism (Nancy 2013:6).

For Nancy, the Christian Text has not only played an important role in the metaphysics of the West, the enclosure, but also in the dis-enclosure of this metaphysics in postmodernity. It is here at the closure of metaphysics, in the linguistic turn, that Nancy (2008) places the Christian Text:

Whether we take it from Paul or John, from Thomas or Eckhart, Francis or Luther, Calvin or Fénélon, Hegel or Kierkegaard, Christianity thus dis-encloses in its essential gesture the closure that it had constructed and that it perfects, lending to the metaphysics of presence its strongest imaginary resource. (p. 10)

If it is given that once something is interpreted into Western language, one can assume that it will be translated into a language that is dominantly determined by Christian Text, and therefore, one can speak of a universalism of the Christian Text from a Western point of view. And because of the media and information industry, that is very often the only point of view that is freely available and therefore dominant.

One could therefore conclude this section by emphasising that there is nothing outside the Christian Text!

Nancy's singular deconstruction of Christianity is still universal in its deconstruction, as universal as Taylor's religion. Nancy, like Taylor, still seeks a singular system by which to interpret and understand the world, and specifically the other - a true monolingualism: a single language of a singular world.

Derrida's auto-deconstruction, and therefore also autodeconstruction of Christian Text, offers maybe an alternative to this monolingualism of a singular world - as there are always other texts and with these texts other worlds.

\section{Beyond the universalism of the Christian Text - There are always other texts}

\author{
- We only ever speak one language ... \\ (yes, but) \\ - We never speak one language ... (Derrida 1998:10)
}


There is nothing outside the Christian Text! (yes, but)

There are always other texts!

I have discussed the first part of this statement following both Taylor and Nancy, concerning the monolingualism of the Christian Text as a cultural-political phenomenon. Derrida (1998) says:

All culture is originally colonial. In order to recall that, let us not simply rely on etymology. Every culture institutes itself through the unilateral imposition of some 'politics' of language. Mastery begins, as we know, through the power of naming, of imposing and legitimating appellations. (p. 39)

This is where the article began - with the question of power and who has the power to name, impose and legitimate appellations and who has the power to create, interpret and consequently act. Derrida is writing these words as an Algerian Jew, speaking French as his first language.

He says, 'We only ever speak one language' (Derrida 1998:10). In this statement, Derrida (1998) is referring to his relationship to French, where French is the monolinguialism that is imposed on the colonial people by the colonial masters:

First and foremost, the monolingualism of the other would be that sovereignty, that law originating from elsewhere, certainly, but also primarily the very language of the Law. And the Law as Language. Its experience would be ostensibly autonomous, because I have to speak this law and appropriate it in order to understand it as if I was giving it to myself, but it remains necessarily heteronomous, for such is, at bottom, the essence of any law. (p. 39)

The monolingualism imposed by the other operates by relying upon that foundation, here, through a sovereignty whose essence is always colonial, which tends, repressively and irrepressibly, to reduce language to the One, that is, to the hegemony of the homogeneous. (pp. 39-40)

In a global world, we only ever speak one language - the language of the West that we speak within the Christian Text and we cannot avoid it. This is a very strong statement. Is it possible to make such strong statements?

Derrida, writing as an Algerian Jew, is writing from the position of somebody who both loves the French language and as somebody who has been subjected to the French colonial masters of Algeria as well as the subjugation of the Jews.

So with all those who have been subjected to speaking and writing in another language than their own, we can ask: Who is the other? Whose language do we speak? Whose language do I speak? In whose world do I live, who interprets my world and who acts in my world according to whose interpretation? I speak the language that has fabricated the world that I live in. I speak the language that has allowed my world (the world I predominantly live in) to appear. It is a world created by this monolingualism of the global media houses that tell me how to interpret Charlie Hebdo. 'It was a terrorist attack by evil fundamentalist terrorist who are against liberty, free speech and democracy and who want to entrap us all in their unfreedom and enslavement'.

Yet, who or what is this one language? Derrida speaks of spectrality (1998:42) in reference to this one language. There are numerous conspiracy theories about who is behind all this, as if this one language is masterminded by an individual or a group of very powerful individuals. But, is that true?

That is the dominant Text and yet there have been numerous other, admittedly smaller, weaker texts, which offer a different interpretation of these events. What are these smaller, weaker texts? Are they not just alternative attempts at a different or alternative monolingualism?

But even these alternative texts, do they not also speak the language of the other? Do I not speak the language of the other, even when I speak my mother tongue? It is always the language of the other, the language that I have inherited.

We always speak only one language - the language of the other!

How to counter this monolingualism when the very words that are used to counter it, belong to it:

All these words: truth, alienation, appropriation, habitation, one'shome [chez-soi], ipseity, place of the subject, law, and so on remain, in my eyes, problematic. Without exception, they bear the stamp of the metaphysics that imposed itself through, precisely, this language of the other, this monolingualism of the other. (Derrida 1998:59)

What are these small, weak alternative stories? They are not really alternative, but deconstructive writing that attacks the body of the language, the only language.

The idea is not to try and focus on these 'alternative languages' as they are just attempts at monolingualism in themselves, but rather to focus on the idea that the monolingualism is not my language, but the language of the spectral other. It is always the language of the other (Derrida 1998:63).

Yet, this relationship to the language of the Other, colonial master is not only the relationship to this colonial language, but it is the relation we have with any language, even our mother tongue:

... we speak only one language - and that we do not own it. We only ever speak one language - and, since it returns to the other, it exists asymmetrically, always for the other, from the other, kept by the other. Coming from the other, remaining with the other, and returning to the other. (Derrida 1998:40)

\section{How to speak? How to think? How to be a practical theologian?}

These questions are not to be answered in a singular universal way, as if one could find the way to speak, to think and to be. These questions are always subjective questions, my 
questions. How to speak, to think and to be a theologian in a world where Charlie Hebdo attracts world leaders to Paris whilst numerically more deaths, but black deaths in Baga, attract not even headlines? How to be a practical theologian in South Africa when my language carries a heavy burden of guilt?

Can I speak, think and be, or should I rather be silent, contemplative and passive? But is silence, contemplation and passivism not already a way of speaking, thinking and being? One cannot avoid to speak, think and be, unless one's speaking is a hearing, which is also a thinking and being. Hearing in the dual sense of the word: hearing as in listening to the other, maybe the victim-in-person (Laruelle 2015:xi) as Laruelle would argue, and hearing as in a court hearing where the victims have a chance to present their case. I live in a world created by a dominant language with its metaphysical system strongly influenced by the Christian Text, but I also know that language, as Derrida argues, resembles a game of blindman's bluff (Derrida 1998:64).

Language is always a reappropriation into some or other system, into some or other closure, as things appear within some or other Erschließung [unlocking] where a single key unlocks the world for us. Yet, there remain events that remain locked, like Ubuntu, or what is happening in the world, where the dominant Erschließung does not satisfy. Derrida argues that every time he writes or speaks, he promises (Derrida 1998:67). Derrida thinks of a language still to come, a kind of messianism (Derrida 1998:68). For him, it is the monolanguage of the other (Derrida 1998:68), the other that is still to come, which brings about this messianism. Thus, for Derrida (1998), the monolingualism of the other has the threatening face of colonial hegemony, but what legitimates the various liberation movements is the 'there is language':

a 'there is language which does not exists', namely that there is no metalanguage, and that $a$ language shall always be called upon to speak about the language - because the latter does not exist. (p. 69)

It is not a matter of it existing sometime in the future, 'it never exists yet' (Derrida 1998:69). Thus, for Derrida, we are left with a language that is always the language of the other that fails lastingly to reach home (Derrida 1998:69). Therefore, we only ever speak one language (the colonial language), but we never speak one language as it fails. It was exactly this failure of the one language that Nancy took up in his work. He placed Christianity right there in that failure of language: the dis-enclosure of the closure of metaphysics.

Laruelle does not focus on the Other and the language always still to come, but the victims of the language that is - listening to the victims-in-person of the language that is and the languages that are. Such listening speaks, in that it makes room for the victim, maybe even the faceless primitive, who indeed comes before the face of Christ, but a silent Christ of the utter abandonment of the crucifixion. Thinking becomes a listening and seeking to hear the voice of the victim-inperson (not the ideological victims), not interpreting her nor understanding her, but allowing her to speak - not in her own voice as that would be patronising, but allowing her to speak in the universalism of the monolingualism that does not exist, by cracking the universalist hold so as to reveal the always other texts still to speak. It is to be speechless, not language-less, in the face of all the victims of the conflict of fundamentalisms. Not to jump on the bandwagon of the liberal ideology of freedom of speech nor to jump on the bandwagon of punishment for blasphemers, but to stay off all bandwagons - because if you speak, even if you think you speak in the name of victims, you are speaking from a bandwagon (just as I am now by making this statement). Therefore, to rather be silent, maybe even devastated, to be crucified in one's language so as to open the doors of heaven that all may go in, the carnival of bandwagons, and may heaven be a symphony or a cacophony of speeches in the name of all the Fathers, who abandoned their speakers and spokespersons.

So, we are back at the Christian metaphor or image or sign, as all there ever is, is the Christian Text ...

$\ldots$ and there will always be other texts ...

\section{Acknowledgements Competing interests}

The author declare that he has no financial or personal relationships which may have inappropriately influenced him in writing this article.

\section{References}

Deleuze, G. \& Guattari, F., 2011, A thousand plateaus: Capitalism and schizophrenia, transl. B. Massumi, University of Minnesota Press, Minneapolis, MN.

Derrida, J., 1997, Of grammatology, transl. G.C. Spivak, The Johns Hopkins University Press, Baltimore.

Derrida, J., 1998, Monolingualism of the other, or the prosthesis of origin, transl. P. Mensah, Stanford University Press, Stanford.

Dussel, E., 1985, Philosophy of liberation, transl. A. Martinez \& C. Morkovsky, Wipf \& Stock Publishers, Eugene, OR.

Laruelle, F., 2015, Intellectuals and power: The insurrection of the victim, François Laruelle in conversation with Philippe Petit, transl. A.P. Smith, Polity Press, Cambridge.

Nancy, J.-L., 2008, Dis-enclosure: The deconstruction of Christianity, transl. B. Bergo, G. Malenfant \& M.B. Smith, Fordham University Press, New York.

Nancy, J.-L., 2013, Adoration: The deconstruction of Christianity II, transl. J. McKeane, Fordham University Press, New York.

Taylor, M.C., 2007, After God, University of Chicago Press, Chicago, IL.

Weber, M., 1930, The protestant ethic and the spirit of capitalism, transl. T. Parsons, Routledge Classics, London. 